\title{
Bài nghiên cứu phải xin rút bài tới hai lần
}

\author{
- sciencevietnam $\boldsymbol{E}$ SciComm (1) August 27, 2021
}

ENHANCED BY Google

SSHPA (27-08-2021) — Mới đây, RetractionWatch đã đưa tin về một vụ việc kỳ lạ. Nhà nghiên cứu Cory Xian (University of South Australia, Úc) đã phải xin rút bài tới hai lần mới được chấp thuận [1].

Tác giả Cory Xian đã phát hiện bài nghiên cứu Release of CXCL12 From Apoptotic Skeletal Cells Contributes to Bone Growth Defects Following Dexamethasone Therapy in Rats của mình trên tạp chí Journal of Bone and Mineral Research (JBMR) có nhiều lỗi sai liên quan tới hình ảnh [2].

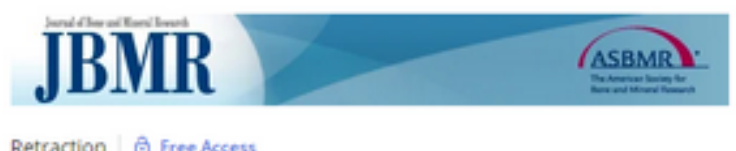

\section{Retraction Statement: Release of CXCL12 From Apoptotic Skeletal Cells Contributes to Bone Growth Defects Following Dexamethasone Therapy in Rats}

(- This article retracts the following: $\checkmark$

First published: 19 August 2021 | https://dol.org/10.1002/jbmr.4425

Retraction of "Release of CXCL12 From Apoptotic Skeletal Cells Contributes to Bone Growth Defects Following Dexamethasone Therapy in Rats" Qian Tang, Yu-Wen Su, Chia-Ming Fan, Rosa Chung, Mohammadhossein Hassanshahi, Yaser Peymanfar, Cory J Xian. The above article, published online on 5 November 2018 in Wiley Online Library

(wileyonlinelibrary.com) and in Volume 34, pp. 310-326, has been retracted by agreement between the authors, the journal's Editor-in-Chief, Professor Roberto Civitelli, the American Society for Bone and Mineral Research, and Wiley Periodicals, Inc. Upon re-inspection of the data presented in the article, the authors identified errors and inaccuracies in more than one figure. Unfortunately, the authors are unable to provide correct images after re-analysis of the original data. Therefore, they have requested for the article to be retracted. After review of the documentation provided by the authors, the ASBMR Research Integrity Panel, the journal's Editor-in-Chief, and Wiley concur with the retraction.

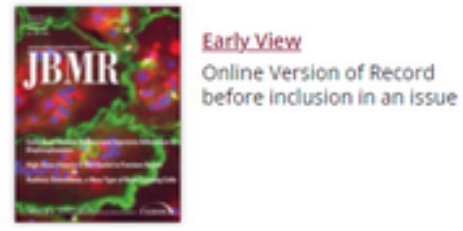

Published on behalf of the American Society for Bone and Mineral Research

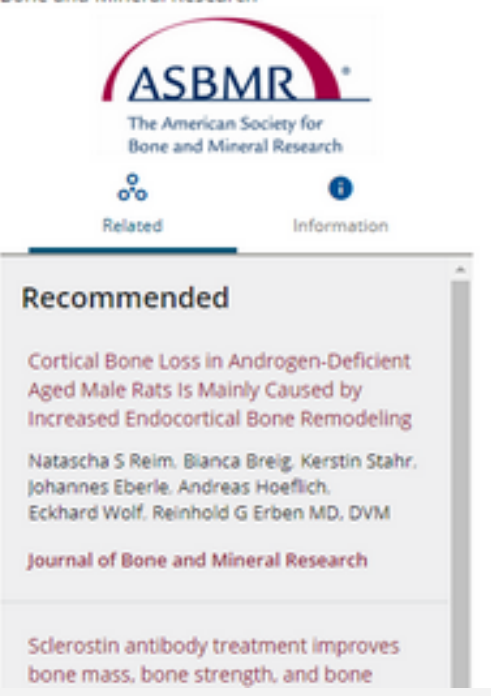

Lần đầu tiên vào tháng 2-2020, sau khi phát hiện hai hình ảnh trong bài có sai sót, nhóm đã yêu cầu rút bài. Tuy nhiên, ban biên tập tạp chí đã quyết định đăng tải một bản Erratum để chỉnh sửa lỗi sai của bài nghiên cứu [3].

Sau đó, vào tháng 7-2020, Xian và các cộng sự lại tiếp tục phát hiện lỗi sai ở 3 hình ảnh khác trong bài. Đến lần thứ hai, nhóm nghiên cứu và ban biên tập đã đồng ý rút bài [4].

Tổng biên tập tạp chí JBMR cho biết trong lần đầu đề nghị rút bài, ban biên tập nhận thấy lỗi sai về sử dụng nhầm hình ảnh có thể được sửa chữa bằng một bản 
Erratum. Tuy nhiên, đến lần thứ hai, quan ngại về tính hợp lệ của bài báo được dấy lên. Cuối cùng, quyết định rút bài đã được đưa ra.

Có thể thấy, cả tạp chí và nhà nghiên cứu đều đã hành động chuẩn mực trong khuôn khổ cho phép để đảm bảo sự trong sạch của nghiên cứu [5]

Tài liệu tham khảo:

[1] Marcus A. (2021). Second time's the charm: The author who requested a retraction twice. RetractionWatch. URL: https://retractionwatch.com/2021/08 /26/second-times-the-charm-the-author-who-requested-a-retraction-twice/

[2] Tang Q, et al. (2019). Retracted: Release of CXCL12 From Apoptotic Skeletal Cells Contributes to Bone Growth Defects Following Dexamethasone Therapy in Rats. Journal of Bone and Mineral Research, 34(2), 310-326.

[3] Tang Q, et al. (2020). Release of CXCL12 from Apoptotic Skeletal Cells Contributes to Bone Growth Defects Following Dexamethasone Therapy in Rats. Journal of Bone and Mineral Research, 35(8), 1612-1613.

[4] JBMR. (2021). Retraction Statement: Release of CXCL12 From Apoptotic Skeletal Cells Contributes to Bone Growth Defects Following Dexamethasone Therapy in Rats. Journal of Bone and Mineral Research, Early View.

[5] Vuong QH. (2020). Reform retractions to make them more transparent. Nature, 582(7811), 149.

\section{(1) Last modified: 8/28/2021 10:01 AM OViews: 4 ff 0 ?ै 0}

\section{Bài liên quan:}

- Tác giả Việt nêu quan điểm về việc rút bài báo khoa học trên Nature

- Lỗi tại Excel

- "Gót chân Achilles" của xuất bản khoa học

- Nghiên cứu khoa học tại những đại học hàng đầu Trung Hoa

- Bốn giáo sư Đại học Kyoto tiêu xài bất chính số tiền hơn 500 triệu yên

\section{Ý kiến bạn đọc (0):}

Comment

Gửi bình luận 